\title{
Isolation and Identification of Phenanthrene-degrading Bacteria and Increasing the Biodegrading Ability by Synergistic Relationship
}

\author{
Zahra Fathi *, Golamhossein Ebrahimipour, Ziba Najmi \\ Department of Microbiology, Faculty of Biological Sciences, Shahid Beheshti University, Tehran, Iran.
}

Received: 5 Jan 2017

Revised: 24 Jan 2017

Accepted: 11 Feb 2017

Corresponding Author:

Zahra Fathi

Department of Microbiology, Faculty

of Biological Sciences, Shahid

Beheshti University, Tehran, Iran.

Phone: +98-9146957953

E-mail:

zfathimicrobiology@gmail.com

\begin{abstract}
Background: Polycyclic aromatic hydrocarbons are a large group of oil contaminants with carcinogenic, mutagenic and teratogenic effects. The release of these compounds in soil destroys animals, plants and microbial diversity and has several negative impacts on physical properties of the soil including the destruction of soil aggregates reduction in pores, and increase in soil bulk density. Many strains of microorganisms isolated have the phenanthrene-degrading ability but this study focused on isolation and identification of a phenanthrene-degrader bacterium for bioremediation of contaminated soils.

Materials and Methods: Enrichment technique was used for isolation and the most effective isolates, were named pseudomonas aeruginosa ZF1 and Serratia marcescens ZF2. The degradation experiments were conducted in the mineral salt medium (MSM) containing phenanthrene as the sole source of carbon and energy. The selection was based on phenanthrene biodegradation abilities. The isolates were identified using morphological, biochemical tests and 16S rDNA sequencing and after 10 days' incubation at $30^{\circ} \mathrm{C}$ and $\mathrm{pH}=7$, the bacterial growth and Phedegrading rate were evaluated by protein assay (Bradford) and gas chromatography (GC), respectively.

Results: Biochemical tests and 16s rDNA gene sequence analysis revealed that isolated bacteria are similar to Pseudomonas aeruginosa ZF1 and Serratia marcescens ZF2 with 99\% similarity. The results showed a mixture of ZF1 and ZF2 bacteria could degrade $83 \%$ at minimum concentrations of $200 \mathrm{ppm}$ of phenanthrene whereas single strain culture of two bacteria had poor degradation abilities (less than 15\%).

Conclusion: Results showed that isolated co-culture bacteria have high potential to degrade phenanthrene with the best results achieved when the enriched consortium was used and this mixture was shown to be an appropriate candidate for bioremediation purposes.
\end{abstract}

Keywords: Phenanthrene; Co-culture; Biodegradation

Please cite this article as: Fathi Z, Ebrahimipour GH, Najmi Z. Isolation and Identification of Phenanthrene-degrading Bacteria and Increasing the Biodegrading Ability by Synergistic Relationship. Res Mol Med. 2017; 5 (2): 22-27

\section{Introduction}

Crude oil is composed of a complex mixture of alicyclic, aliphatic and aromatic hydrocarbons (1). The aromatic hydrocarbons have benzene (C6H6) in their structure (2). Polycyclic aromatic hydrocarbons (PAHs) are a large group of organic compounds with two or more fused aromatic rings in linear, angular, or cluster arrangements. These compounds have a relatively low solubility in water, but they are highly lipophilic and very stable in the environment $(2,3)$.
Some PAHs are toxic, mutagenic and carcinogenic, and represent a potential threat to human health. These compounds are listed as priority pollutants by the US environmental protection agency (4-6). Phenanthrene (Phe) is tri-cyclic aromatic hydrocarbon that is found in high concentrations in polycyclic aromatic hydrocarbon (PAH)-contaminated sediments, surface soils and waste sites (7). Phe is a major constituent of coal derivatives and oil fuels. Phe is 
also reported to act as human skin photosensitizer, mild allergen and mutagen in bacterial systems under certain conditions. It has also been proved to induce sister chromatid exchanges and to be a strong inhibitor of gap junction intercellular communication $(8,9)$.

Bioremediation which is based on microbial transformation and degradation is one of the most promising methods applied in the field of environmental biotechnology to clean up contaminated environments $(10,11)$. A large number of bacteria with PAHdegrading capabilities have been reported as able to either completely assimilate a defined range of compounds or carry out their transformation to different extents (12). In other words, during the bioremediation process, PAHs that are toxic and hazardous compounds are transformed to non-toxic compounds by microorganisms. However, the success of bioremediation projects has been limited by the scarcity of microorganisms capable of degrading a broad range of PAHs (13).

The potential for degradation of PAH compounds in soil has been a research area of great interest in recent years and many efforts have been made to isolate bacteria that could degrade PAH compounds. This study aims to isolate and identify effective bacteria in Phe degradation available in Arak petrochemical wastewater located in the center of Iran and to determine the capacity of these bacteria for degradation of these compounds.

\section{Materials and methods \\ Sampling}

Samples were collected from wastewater of Arak Petrochemical located at the center of Iran. Sampling site had been naturally exposed to oil pollution because of natural oil seepage over decades. The temperature and $\mathrm{pH}$ of the sampling sites in June were $30{ }^{\circ} \mathrm{C}$, and 7 respectively. Samples were aerated every $30 \mathrm{~min}$ and transferred to the laboratory in sterile conditions on ice within 24 hours and stored at $4{ }^{\circ} \mathrm{C}$ until they were used.

\section{Materials and chemicals}

A stock solution of Phe was prepared by dissolving 1 $\mathrm{g}$ of Phe in $100 \mathrm{ml}$ acetone $(100 \mathrm{mg} \mathrm{L}-1)$. Mineral salts medium (MSM) was composed of $1.0 \mathrm{~g}$ of $\mathrm{NH} 4 \mathrm{Cl}, 5.0 \mathrm{~g} \mathrm{KH} 2 \mathrm{PO} 4,0.1 \mathrm{~g} \mathrm{MgSO} 4 \times 7 \mathrm{H} 2 \mathrm{O}, 5 \mathrm{mg}$ of $\mathrm{Fe}(\mathrm{SO} 4) 2,1.0 \mathrm{ml}$ of trace elements solution and $2.0 \mathrm{ml}$ of Phe solution as the carbon and energy source. The trace element solution contained $(13,14)$ : $23 \mathrm{mg} \mathrm{MnCl} 2 \times 2 \mathrm{H} 2 \mathrm{O}, 30 \mathrm{mg} \mathrm{MnCl} 4 \times \mathrm{H} 2 \mathrm{O}, 31 \mathrm{mg}$ $\mathrm{H} 3 \mathrm{BO} 3,36 \mathrm{mg} \mathrm{CoCl} 2.6 \mathrm{H} 2 \mathrm{O}, 10 \mathrm{mg} \mathrm{CuCl} 2 \times 2 \mathrm{H} 2 \mathrm{O}$, $20 \mathrm{mg} \mathrm{NiCl} 2 \times 6 \mathrm{H} 2 \mathrm{O}, 50 \mathrm{mg} \mathrm{ZnCl} 2$, and $30 \mathrm{mg}$ $\mathrm{Na} 2 \mathrm{MoO} 4 \times 2 \mathrm{H} 2 \mathrm{O}$ per liter. Final $\mathrm{pH}$ of MSM was adjusted at 7.0 using $100 \mathrm{mM} \mathrm{NaOH}$ (15). In order to produce solid medium, $15 \mathrm{~g}$ agar was added to MSM. All the chemicals were purchased from Merck (Darmstadt, Germany), except for the followings: $\mathrm{CaCl}$, glucose, starch, arabinose (Sigma-Aldrich, Germany); Peptone, SIM and Agar (Difco); MRVP and TSI (Oxid); MgSO4.7H2O and NH4Cl (Riedelde Haën).

\section{Isolation and identification of Phe-degrading bacteria}

In order to isolate of Phe-degrading bacteria, $10 \mathrm{ml}$ of the sample was transferred into the conical flask containing $100 \mathrm{ml} \mathrm{MSM}$ supplemented with $200 \mathrm{mg} / \mathrm{l}$ Phe $(\mathrm{pH} 7)$ and incubated at $30{ }^{\circ} \mathrm{C}$ on a rotary shaker at $140 \mathrm{rpm}$ for one week. Phe utilization in the enriched cultures was monitored by the increase in bacterial biomass (absorbance at $600 \mathrm{~nm}$ ). Then, $1 \mathrm{ml}$ of the enriched culture was transferred to a same fresh medium and subcultures were performed four times. At the end of the enrichment process, a 10-fold serial diluted concentration of inoculated MSM was made, cultured on MSM agar plates and incubated at $30{ }^{\circ} \mathrm{C}$. Colonies with clearing zone (reflects degradation of Phe) were picked and purified by streaking several times on MSM agar. Purified strains were tested for Phe degradation ability as follows. Equal concentration of any of the colonies (an absorbance of 0.3 at $600 \mathrm{~nm}$ ) was made and cultured in $250 \mathrm{ml}$ flasks containing MSM and incubated at 30 ${ }^{\circ} \mathrm{C}$ for 10 days (140 rpm). MSM with no bacterial inoculums was used as a control. Experiments were conducted in triplicate. At two-day intervals, $1 \mathrm{ml}$ of each medium was taken for measurement of bacterial growth by protein assay with Bradford's method (16, 17). Protein yield was considered as a scale for bacterial growth and Phe degradation. The most produced protein was the most Phe degradation.

In order to identify the isolate, the morphological and biochemical characterization was done referring to Bergey's manual of determinative bacteriology (18). Also, genomic DNA was extracted using phenol/chloroform/isoamyl alcohol according to Sambrook et al., 2001 method (19). 16S rDNA gene fragment was amplified by polymerase chain reaction (PCR) with a set of universal primers including F 27 (5- AGA GTT TGA TCC TGG CTC AG -3) and R 1510 (5- GGT TAC CTT ACG ACT T -3). The PCR amplification mixture of $16 \mu$, contained the bacterial DNA (of about $200 \mathrm{ng}$ ), $1 \mu \mathrm{l}$ (3 units) of Taq DNA polymerase, $5 \mu \mathrm{l}$ of Taq buffer (TAPS, pH 8.8, 3mM $\mathrm{MgCl} 2,50 \mathrm{mM} \mathrm{KCl}), 5 \mu \mathrm{l}$ of $2 \mathrm{mM}$ dNTP mix and 5 $\mu \mathrm{l}$ of each primer $(10 \mathrm{pM} / \mu \mathrm{l})$. Amplification program was set for 30 cycles; each consisted of a denaturation at $96{ }^{\circ} \mathrm{C}$ for $10 \mathrm{~s}$, an annealing at $50{ }^{\circ} \mathrm{C}$ for $10 \mathrm{~s}$ and an extension step at $60{ }^{\circ} \mathrm{C}$ for $4 \mathrm{~min}$, followed by a final extension step at $72{ }^{\circ} \mathrm{C}$ for $5 \mathrm{~min}$. 
Subsequently, PCR products were electrophoresed on $1 \%$ agarose gel and visualized using ethidium bromide. DNA fragments were sequenced by a sequencer (SEQLAB, Germany). Finally, all the sequences were compared with reference sequences in NCBI databases (http://WWW .ncbi.nlm.nih.gov/Genbank) using BLAST software.

\section{Evaluation of bacterial growth with Phe}

For estimating co-culture (with 1:1 ratio) growth based on total protein production, during 10 days at $48 \mathrm{~h}$ intervals, bacteria were harvested by centrifugation of $1 \mathrm{ml}$ of the inoculated MSM at 8000 $\mathrm{g}$ for $10 \mathrm{~min}$. Then the pellet was suspended in $1 \mathrm{ml}$ of Ringer's solution (111.2 mM NaCl, $5.7 \mathrm{mM} \mathrm{KCl}$, $2.25 \mathrm{mM} \mathrm{CaCl} 2$, and $2.4 \mathrm{mM} \mathrm{NaHCO} 3$ ), vortexed and centrifuged $(8000 \mathrm{~g}$ for $10 \mathrm{~min})$ again. For cell lysing, the pellet was resuspended in $1 \mathrm{ml}$ of distilled water and $0.5 \mathrm{ml}$ of $0.3 \mathrm{M} \mathrm{NaOH}$ and then vortexed. The suspension was incubated at $90{ }^{\circ} \mathrm{C}$ for $60 \mathrm{~min}$. This cell lysate was used for protein staining done by Bradford's method (20). Briefly, Bradford's solution was prepared as follows: dissolve $100 \mathrm{mg}$ Coomassie Brilliant Blue G-250 in $50 \mathrm{ml}$ 95\% ethanol, add 100 $\mathrm{ml}$ 85\% (w/v) phosphoric acid was added. Five milliliters of Bradford's solution was added to each glass tube containing cell lysis and a blank glass tube (containing $1 \mathrm{ml}$ of distilled water and $0.5 \mathrm{ml}$ of $0.3 \mathrm{M}$ $\mathrm{NaOH}$ ) while stirring. After incubation in the dark for $20 \mathrm{~min}$, the absorbance of the supernatant was measured at $595 \mathrm{~nm}$ (Shimadzu, UV-120-02; Japan). The results were checked against the standard curve of serial dilutions of $0,10,50,150$, and $200 \mathrm{mg} / \mathrm{l}$ bovine serum albumin (BSA). The degradation rate was evaluated by gas chromatography (GC) after 10 days (14).

\section{Extraction and analysis of Phe degradation}

After 10 days, the concentration of Phe in the mixed sample, isolated samples and control flask (containing $100 \mathrm{ml}$ MSM) was determined according to $\mathrm{Wu}$ et al (21). $50 \mathrm{ml}$ ethyl acetate was added to the culture medium and shaken for $15 \mathrm{~min}$. After forming two phases, Phe-containing non-polar organic solvent phase was collected and the aqueous phase was reextracted by another aliquot of $50 \mathrm{ml}$ ethyl acetate. Finally, the two extracts were combined together, dried by anhydrous $\mathrm{Na} 2 \mathrm{SO} 4$ and the volume was adjusted to $100 \mathrm{ml}$. Extract samples were analyzed by GC-FID. GC-FID was equipped with an HP-5MS fused silica capillary column $(60 \mathrm{~m} \times 0.25 \mathrm{~mm}$ ID $\times$ $0.251 \mathrm{~m}$ thickness, Agilent Technologies, USA) with the injector and detector temperature of $280{ }^{\circ} \mathrm{C}$ and $300{ }^{\circ} \mathrm{C}$, respectively. Nitrogen was used as the carrier gas. Oven temperature program was $80{ }^{\circ} \mathrm{C}$ (for 2 min) to $120{ }^{\circ} \mathrm{C}$ at a rate of $10{ }^{\circ} \mathrm{C} / \mathrm{min}$ and from 120
${ }^{\circ} \mathrm{C}$ to $300{ }^{\circ} \mathrm{C}$ at a rate of $4{ }^{\circ} \mathrm{C} / \mathrm{min}$ and held at $300{ }^{\circ} \mathrm{C}$ for $15 \mathrm{~min}$. The identification and quantification of chemicals were conducted based on matching their retention times of standards (21).

\section{Results}

Enrichment of Phe-degrading bacteria and selection of the novel strains

The clear zone around isolated colonies on MSM agar was observed after 4, 5 and 6 days of culture, respectively. Colonies with clear zones were labeled as ZF1 and ZF2. Figure 1 shows the colony of the isolated bacterium on MSM agar.

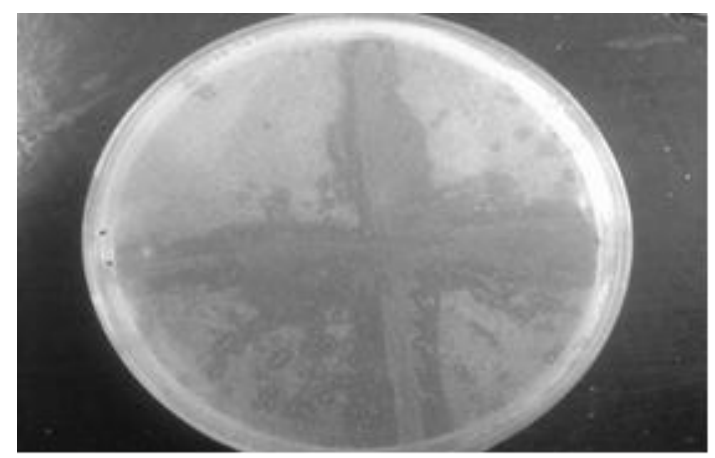

Figure 1. Clear zone on Phe-sprayed MSM agar made by Phe degrading.

\section{Identification of selected strains}

A 1516 bp nucleotide DNA fragment of 16S rRNA amplified from the ZF1 isolate and $1436 \mathrm{bp}$ nucleotide DNA fragment of 16S rRNA amplified from the ZF2, were submitted to the BLAST in order to find a homology with other 16S rDNA sequences. Comparing the sequence of the 16S rDNA gene of the isolation with the sequences in GenBank revealed that the ZF1 isolate is similar to Pseudomonas aeruginosa and the ZF2 isolate is Serratia marcescens with 99\% similarity. Morphology and biochemical tests (Table 1) with comparing the sequence of the 16S rDNA gene of the isolation revealed that the isolates were strains of Pseudomonas aeruginosa and Serratia marcescens.

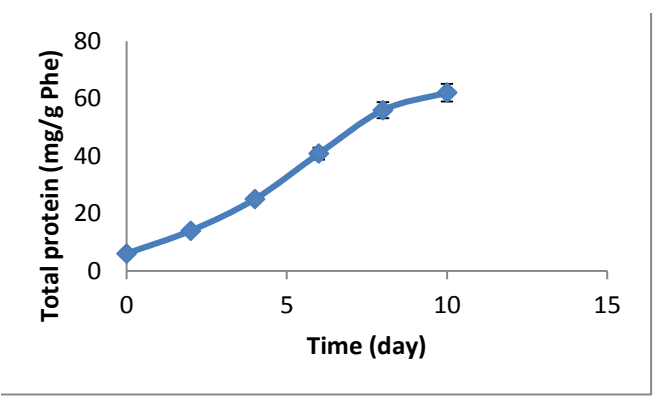

Figure 2. The growth rate for mixed culture with protein assay during 10-day incubation at $30^{\circ} \mathrm{C}, \mathrm{pH} 7$ and $120 \mathrm{rpm}$. 
Assessment of mixed bacterial growth

Mixed bacterial growth charts (by means of protein assay) indicated that mixed bacteria had more growth than separated bacterial. Low growth of bacteria in separate cultures was due to producing intermediate materials that are toxic to bacteria.

Table 1. Morphological and biochemical features of isolations ZF1 and ZF2.

\begin{tabular}{lll}
\hline Morphological and biochemical features & $\mathbf{Z F 1}$ & $\mathbf{Z F 2}$ \\
\hline Cell morphology & $\begin{array}{l}\text { Gram-negative bacilli, non-spore, and non- } \\
\text { capsule forming }\end{array}$ & $\begin{array}{l}\text { Gram-negative bacilli, non-spore, and } \\
\text { capsule forming }\end{array}$ \\
Colony morphology & $\begin{array}{l}\text { Circular, smooth-edge, glistening, and yellow- } \\
\text { white }\end{array}$ & $\begin{array}{l}\text { Circular, smooth-edge, convex, } \\
\text { glistening, and pink } \\
\text { Oxidase, catalase, mobility, urease, aerobic, } \\
\text { citrate reduction, nitrification, indole } \\
\text { production, Utilized d-glucose, Utilized starch }\end{array}$ \\
Positive reactions & $\begin{array}{l}\text { Acid-fast, H2S production, Utilized d-glucose, d-fructose, } \\
\text { maltose, d-xylose }\end{array}$ \\
fructose, maltose, d-xylose & $\begin{array}{l}\text { Oxidase, Acid-fast, H2S production, and } \\
\text { indole production, nitrification, Utilized } \\
\text { starch }\end{array}$ \\
Tolerance range pH & $5-10$ & $6-10$ \\
Tolerance range Temperature & $20-50^{\circ} \mathrm{C}$ & $15-45^{\circ} \mathrm{C}$ \\
\hline
\end{tabular}

Whenbacteriawerecultivatedinamixture, intermediate materials reducedby co-metabolism activity.Analysis of total protein charts showed, two mixed cultures of bacteria had low growth rate in the first 24 hours after inoculation and growth rate increased in two

(a)

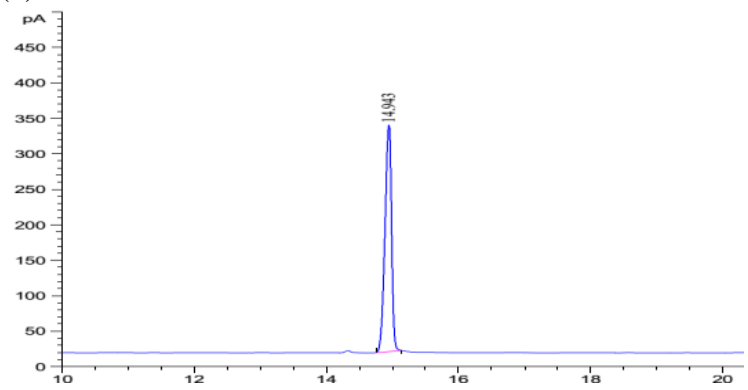

(c)

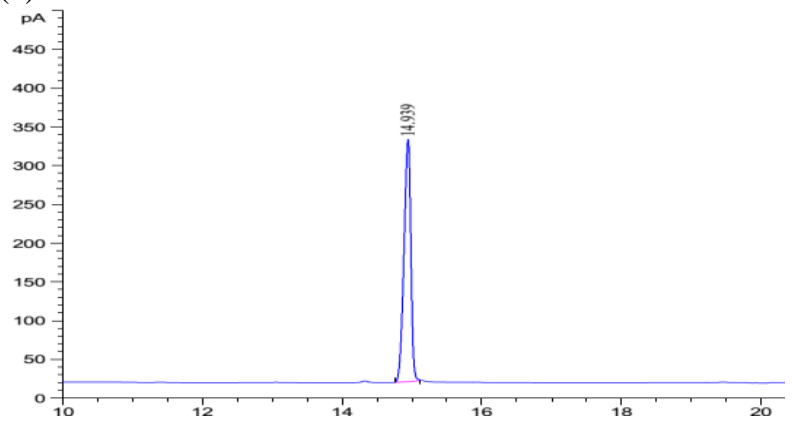

eight in two to eight days after inoculation and it reduced again in the last days (Figure 2). Slow growth in the last days was due to the reduction in the carbon and energy source and increase in waste materials.

(b)

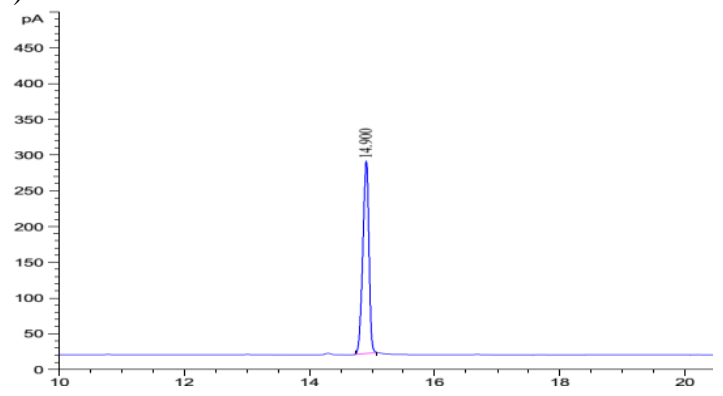

(d)

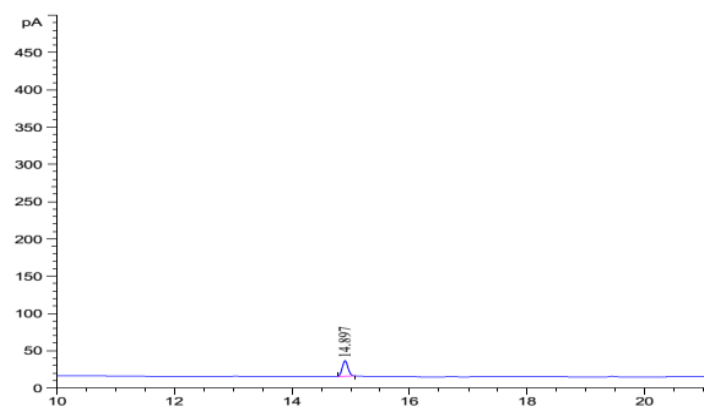

Figure 3. Obtained Chromatograms after 10 days of incubation at $30{ }^{\circ} \mathrm{C}, \mathrm{pH} 7$ and $120 \mathrm{rpm}$.

a) Phe peak at $100 \mathrm{ml}$ MSM containing $200 \mathrm{mg} / \mathrm{l}$ Phe in bacteria-free medium (control).

b) Remaining Phe peak at $100 \mathrm{ml}$ MSM containing $200 \mathrm{mg} / 1$ Phe with ZF1 bacteria.

c) Remaining Phe peak at $100 \mathrm{ml}$ MSM containing $200 \mathrm{mg} / \mathrm{l}$ Phe with ZF2 bacteria.

d) Remaining Phe peak at $100 \mathrm{ml}$ MSM containing $200 \mathrm{mg} / \mathrm{l}$ Phe with a mix of 2 bacteria (ZF1 and ZF2). 
Phe degradation analyses

Degradation rate was calculated with the area under the graph of GC to graphic peak. The results of GC analysis showed that the individual culture of bacteria can degrade Phe less than $15 \%$, during10 days. To determine the performance of two mixture bacteria in degradation of Phe, the mixture of two bacteria were added to $100 \mathrm{ml} \mathrm{MSM}$ containing $200 \mathrm{mg} / \mathrm{l}$ Phe until the OD600 $\mathrm{nm}$ reached up to 0.15 . Culture media were incubated at $\mathrm{pH} 7,30{ }^{\circ} \mathrm{C}$ and $120 \mathrm{rpm}$ for 10 days.

Table 2. The amount of pure strain and mix isolated strains biodegradation after 10 days of incubation at $100 \mathrm{ml}$ MSM containing $200 \mathrm{mg} / \mathrm{l}$ Phe at $30^{\circ} \mathrm{C}, \mathrm{pH} 7$ and $120 \mathrm{rpm}$.

\begin{tabular}{ll}
\hline Bacteria & Phe biodegradation percent \\
\hline ZF1 & $13 / 7 \pm 2$ \\
ZF2 & $5 \pm 1 / 2$ \\
Mix of 2 bacteria (ZF1 and ZF2) & $83 / 6 \pm 4$
\end{tabular}

This mixture could degrade more than $83 \%$ (Table 2) of the Phe at this time. GC analysis chromatogram is shown in Figure 3 and Phe remains during 10-day incubation are shown in Figure 4.

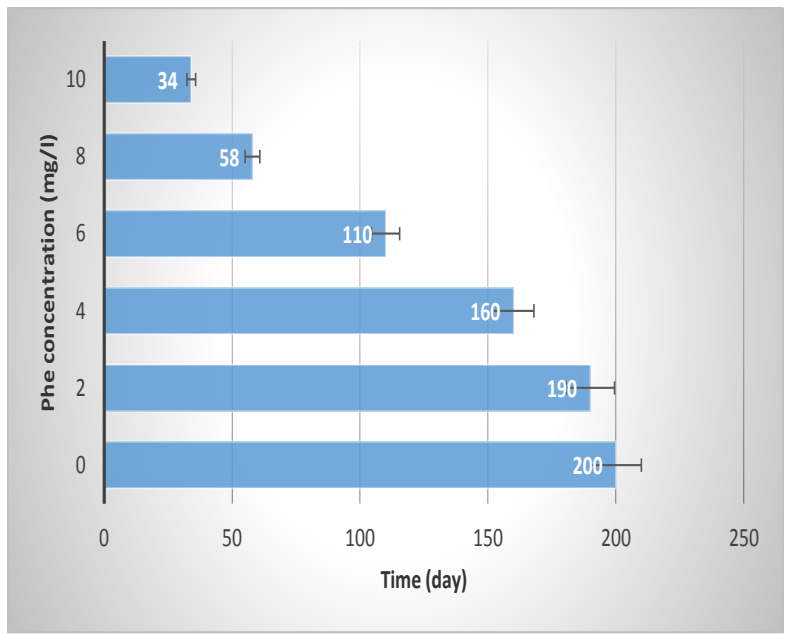

Figure 4. GC chromatograph from Phe remains concentration (initial Phe concentration $200 \mathrm{mg} / \mathrm{L}$, during 10-day incubation by a mixed culture of two bacteria.

\section{Discussion}

Considering the dangers of entering PAH compounds (especially, wastewaters as the main source of the environmental contaminants) to the environment and their effects on humans and other organisms, removing these compounds are extremely important. These compounds are considered as a major threat to aquatic and soil ecosystems $(22,23)$. For this reason, these compounds are considered as a serious threat to humans and other organisms (24). In this study, two bacteria from petrochemical wastewater having high potential to degrade Phe had been isolated. According to the results, this consortium could be valuable in bioremediation of PAHs-contaminated environments. The mixed culture had outstanding performance with a Phe degradation rate of more than $83 \%$ when compared with single strains (less than 15\%). The present study didn't examine the reasons behind the increase in power to Phe degrading in consortium form. However, further research in the field of PAHsdegradation was showed, ability to break down increased in the mixed culture with synergistic effects. Also, in the mixture growth of bacteria, increasing the enzymatic capacity involved in the degradation of intermediate compounds, biosurfactant production, production of compounds essential for growth can be the attributed reasons to this increased functionality by synergistic effects $(25$, $26,13)$. When a single strain of the bacteria entered the environment, the began to degrade but after a limited amount of growth, the degradation and growth stopped. Stopping bacterial growth was due to the toxicity of the intermediate compounds. The ability of the single bacterial enzyme was low and therefore it was not able to degrade these intermediate compounds and these compounds increased in the environment and stopped growth. In the mixture growth of bacteria, due to increasing a variety of enzymes involved in degradation of intermediate compounds, these compounds were degraded and their toxicity decreased. The ability of single bacterial enzyme was low and therefore it was not able to break down these intermediate materials and the increase of these materials in the environment would stop growth. Two strains of bacteria isolated in this study with the ability to degradation of Phe and then they were identified using morphological and biochemical tests. According to Han et al (2006) homology with $99 \%$ similarity expresses identity in strain level, homology with $97 \%$ to less than $99 \%$ similarity expresses identity in genus level and homology with $93 \%$ to less than $97 \%$ similarity expresses identity the new genus and new species (27). According to the above cases ZF1 bacteria with 99\% similarity to Pseudomonas aeruginosa, and ZF2 bacteria with $99 \%$ similarity to Serratia marcescen, are probably the strains of Pseudomonas aeruginosa and Serratia marcescen. Due to the power of the consortium in Phe degradation, further studies on the degradation effect of this consortium on other PAHs such as anthracene, fluorene and pyrene will be useful.

\section{Acknowledgments}

This work was supported by Shahid Beheshti 
University of Tehran, Laboratory of Industrial Biotechnology.

\section{Author Contributions}

All of the authors performed in this study. EG supervised the experiment, NZ advised and FZ was a researcher. All authors discussed the data and commented on the manuscript.

\section{Conflict of Interest}

The authors declare that they have no conflict of interest in this work.

\section{References}

1. Atlas RM, Richard B. Microbiology ecology, fundamentals and application. Microbiol Interaction Xenobiotic Inorganic Pollut. 1946; 13(511): 517-29.

2. McMurry J. In Aromatic hydrocarbons. Organic Chemistry.5th edition, New York: Thomas learning, 2000. p 120-180.

3. Johnsen AR, Wick LY, Harms H. Principle of microbial PAHdegradation in soil. Environ Pollut. 2005; 133(1): 71-84. PMID: 15327858

4. Heitkamp MA, Cerniglia CE. Mineralization of polycyclic aromatic hydrocarbons by a bacterium isolated form sediment blow an oil field. Appl Environ Microbial. 1988; 54(6): 1612-4. PMID: 3415226

5. Bayoumi RA. Bacterial bioremediation of polycyclic aromatic hydrocarbons in heavy oil contaminated soil. J Appl Sci Res. 2009; 5: 197-211.

6. Kucerova R. Application of Pseudomonas putida and Rhodococcus sp. by biodegradation of $\mathrm{PAH}(\mathrm{S}), \mathrm{PCB}(\mathrm{S})$ and nel soil samples from the hazardous waste dump in Pozdatky (Czech republic). Rudarsko-geološko- naftni zbornik.18, 97-101.

7. Abd-Elsalam H, Hafez E, Hussain AA. Isolation and Identification of Tree-Rings Polyaromatic Hydrocarbon (Anthracene and Phenanthrene) Degrading Bacteria. AmericanEurasian J Agric Environ Sci. 2009; 5(1): 31-8.

8. Coral G, Karagoz S. Isolation and characterization of phenanthrene-degrading bacteria from a petroleum refinery soil. Ann Microbiol. 2005; 55(4): 255-9.

9. Wilson SC, Jones KC. Bioremediation of soil contaminated with polynuclear aromatic hydro-carbons (PAHs): a review. Environ Pollut. 1993; 81(3):229-49. PMID: 15091809

10. Atlas RM, Cerniglia CE. Bioremediation of petroleum pollutants. Biosci. 1995; 45(5):332-8.

11. Wattiau P. Microbial aspects in bioremediation of soils polluted by polyaromatic hydrocarbons. In: Agathos SN, Reineke W, at al. Biotechnology for the Environment: Strategy and Fundamentals. Netherlands: Kluwer Academic Press; 2002. P 6989.

12. Coulon F, McKew BA, Osborn AM, McGenity TJ, Timmis $\mathrm{KN}$. Effects of temperature and biostimulation on oil-degrading microbial communities in temperate estuarine waters. Environ Microbial. 2007; 9(1): 177-86. PMID: 17227422
13. Shahriari Moghadam M, Ebrahimipour G, Abtahi B, Ghassempour A. Biodegradation of polycyclic aromatic hydrocarbons by a bacterial consortium enriched from mangrove sediments. J Environ Health Sci Eng. 2014; 12(1): 114. PMID: 25436114

14. Tian L, Ma P, Zhong JJ. Kinetics and key enzyme activities of phenanthrene degradation by Pseudomonas mendocina. Process Biochem. 2002; 37(12): 1431-7.

15. Kavynifard A, Ebrahimipour GH, Ghassempour A. Individually and Synergistic Degradation of Hydrocarbons by Biosurfactant Producing Bacteria. Res. Mol. Med. 2016; 4(1): 3644. 290. doi 10.7508/rmm.2016.01.006

16. Kavynifard A, Ebrahimipour G, Ghasempour A. ptimization of crude oil degradation by Dietzia cinnamea KA1, capable of biosurfactant production. J Basic Microbiol. 2016; 56(5): 566-75. PMID: 26615815

17. Kelly, I and Cerniglia, CE. The metabolism of phenanthrene by a species of Mycobacterium. J. Ind. Microbiol. 1991; 7: 19-26.

18. Holt JG, Krieg, NR, Sneath PH, Staley JT, Williams ST. Bergey's Manual of Determinative Bacteriology, $9^{\text {th }}$ edition, Baltimore, Williams \& Wilkins, 1994.

19. Sambrook J, Fritsch E, Maniatis T. Molecular cloning: a laboratory manual. 2001.

20. Bradford MM. A rapid and sensitive for the quantitation of microgram quantitites of protein utilizing the principle of proteindye binding. Anal Bio chem. 1976; 72: 248-254. PMID: 942051

21. Churchill SA, Harper JP, Churchill PF. Isolation and characterization of a Mycobacterium species capable of degrading three- and four-ring aromatic and aliphatic hydrocarbons. Appl Environ Microbiol. 1999; 65(2): 549-52.

22. Eghtesadi-Araghi P, Haffner PD, Drouillard K, Maghsoudlou W. Polycyclic Aromatic Hydrocarbons contaminants in Black- lip (Pearl) Oyster Pinctadamargaritifera from Kish Island (Persian Gulf). Iranian J Fisheries Sci. 2011; 10(1): 25-34.

23. Hassanshahian M, Emtiazi G, Cappello S. Isolation and characterization of crude oil degrading bacteria from the Persian Gulf and the Caspian Sea. Mar Pollut Bull. 2012; 64(1): 7-12. PMID: 22130193

24. Chen CW, Chen CF. Distribution origin and potential toxicological significance of polycyclic aromatic hydrocarbons (PAHs) in sediments of Kaohsiung Harbor, Taiwan. Marine Pollution Bulletin. 2011; 63(5-12): 417-23. doi 10.1016/j.marpolbul.2011.04.047

25. Sugiura, K, Ishihara, M, Shimauchi, T, Harayama, S Physicochemical properties and biodegra dability of crude oil. Environ Sci Technol. 1997; 31(1): 45-51. doi 10.1021/es950961r

26. Casellas M, Grifoll M, Sebate J, Solanas AM. Isolation and characterization of a fluorenone-degrading bacterial strain and its role in synergistic degradation of fluorene by a consortium. Canadian J Microbiol. 1998, 44(8): 734-42. doi org/10.1139/w98066

27. Han XY. Bacterial identification based on 16S ribosomal RNA gene sequence analysis. In: Tang YW, Stratton CW. Advanced techniques in diagnostic microbiology. Springer. 2006; 323-6. 